Brit. J. industr. Med., 1961, 18, 93.

\title{
CHRONIC RESPIRATORY DISEASE IN A RANDOM SAMPLE OF MEN AND WOMEN IN THE RHONDDA FACH IN 1958
}

\author{
BY
}

\author{
I. T. T. HIGGINS and A. L. COCHRANE
}

From the Pneumoconiosis Research Unit, Llandough Hospital, Penarth, Glamorgan

(RECEIVED FOR PUBLICATION JULY 15, 1960)

To investigate the high death rates for bronchitis in South Wales miners a survey of respiratory symptoms and ventilatory capacity in $90 \%$ of a random sample of 600 men between the ages of 35 and 64 and 200 women between 55 and 64 living in the Rhondda Fach was carried out. The sample of men was stratified by age and occupation, 100 miners and ex-miners, and 100 non-miners being studied in each decade.

The higher prevalence of symptoms and lower mean indirect maximum breathing capacity (I.M.B.C.) of the miners and ex-miners, observed previously, was confirmed and within the mining group there was little relation of symptoms to radiological category of pneumoconiosis. Miners and ex-miners with progressive massive fibrosis had a lower mean I.M.B.C. than the rest at all ages.

Analysis of symptoms and I.M.B.C. by length of time spent working on the coal-getting shift in both miners and ex-miners did not suggest that the total dust dosage to which a man had been exposed during his working life was closely related to chronic respiratory disease. A lower prevalence of symptoms and a higher mean indirect M.B.C. was found in those who had worked for under one year on the coal-getting shift. Above one year no clear pattern of symptom prevalence was discerned although there was a slight downward trend in the mean indirect M.B.C. with increased time spent working on the coal-getting shift. When working miners alone were considered the reduction in ventilatory function with increasing duration of work was slightly greater.

Dust exposure alone seemed unlikely to account for all the excess respiratory disease in miners compared with the rest of the community and other possible explanations are discussed.

The women recorded a lower prevalence of symptoms than the men who had never worked in mining. This prevalence was, however, higher than that previously found in rural areas in Wales and Scotland. The mean indirect M.B.C. recorded for the women in this survey was also lower than that observed in Scots women.

Analysis of the findings in the women according to the occupation of their husbands showed that miners' wives recorded a higher prevalence of symptoms and lower mean indirect M.B.C. than non-miners' wives, suggesting the importance of social rather than occupational factors in miners.

Smoking was associated with an increased prevalence of symptoms and lower indirect M.B.C. in the men but not in the women. Differences in smoking habits could not, however, account for the differences between miners and non-miners, as these remained after standardization for smoking.

National mortality rates suggest that South Wales coal-miners are unduly prone to bronchitis. The standardized mortality ratios (S.M.R.) for bronchitis of miners between the ages of 20 and 64 were 254 in the anthracite area and 207 in the rest of Glamorgan (Registrar-General, 1958), figures which may be compared with 147 for Cheshire and Lancashire,

and 80 for Derbyshire (Higgins, Cochrane, Gilson, and Wood, 1959). While these mortality statistics are of course liable to some regional variation in death certification, they rank the areas for chronic respiratory disease in the same order as our morbidity studies (Carpenter, Cochrane, Gilson, and Higgins, 1956; Higgins, Oldham, Cochrane, and 
Gilson, 1956; Higgins, et al., 1959) of random samples of the community have done and it seems justifiable therefore to accept them as a reasonably close approximation to the truth. The question that immediately follows is: Why should South Wales coal-miners have between two and three times as much bronchitis as coal-miners in other areas ?

In 1954 we attempted a study of bronchitis in a random sample of men in the Rhondda Fach using a standardized questionnaire. The sample investigated at that time was small and subsequent modification of the questionnaire has made it difficult to compare the results in the Rhondda with those established in later surveys in other areas of Great Britain. The obvious desirability of providing comparable results for the Rhondda and the expectation that aetiological factors should be more obvious in an area where the disease prevalence is highest led us to undertake a further study of respiratory disease there in 1958 . This paper records our findings.

\section{The Random Sample}

The population of the Rhondda Fach, originally enumerated by private census by Cochrane and his colleagues (Cochrane, Cox, and Jarman, 1952), was rechecked in 1958. The sample studied was drawn using random numbers from this population.

It consisted of 600 men between the ages of 35 and 64 . In each decade there were 200 men, 100 miners and ex-miners, and 100 men who had never worked in mining. Previous radiological studies (Cochrane et al., 1952; Cochrane, Davies, Chapman, and Rae, 1956) suggested that of the 100 miners and ex-miners there would be about 50 with and 50 without pneumoconiosis and that of those with pneumoconiosis about 10 would have progressive massive fibrosis.

In order to investigate further the high S.M.R. from bronchitis of miners' wives, to which the Registrar-General has alluded in his last two Decen- nial Mortality Supplements (Registrar-General, 1938 and 1958) we included a random sample of 200 women between the ages of 55 and 64 . The number of men and women living in the area, the number sampled, the response rate, and number finally analysed are shown in Table 1.

Methods and Procedure.-The methods and procedure were similar to those used previously (Higgins and Cochran, 1958). Respiratory symptoms were recorded using a questionnaire comparable with that used on all previous surveys except the Rhondda investigation of 1954 already mentioned (Higgins et al., 1956; 1959). The questionnaire was essentially the same as that recently approved by the Medical Research Council's Bronchitis Committee. Occupational histories from the time of leaving school and domiciliary histories from birth were obtained. The $\mathbf{0 . 7 5}$ second forced expiratory volume $\left(\right.$ F.E.V. ${ }_{\cdot 0.75}$ ) was measured and expressed as the indirect maximum breathing capacity (I.M.B.C.) by multiplying by 40 (McKerrow, McDermott, and Gilson, 1960). Standing and sitting heights and weights were measured and a postero-anterior chest radiograph was taken.

Members of the sample were visited in their homes and asked to participate in the investigation. Appointments were made and transport to and from the hall where the tests were carried out was offered.

\section{Results}

Table 2 shows the mean ages and main measurements in each group. The decline in mean height with age noted previously in the Vale of Glamorgan (Higgins, 1957) is again seen. The miners and ex-miners over 45 years were on the average significantly shorter and at all ages lighter than the corresponding non-miners. The mean heights of the non-miners are half to one inch above those found in the survey of the population of Great Britain carried out by the Ministry of Food (Kemsley, 1950) in 1943.

TABLE 1

RANDOM SAMPLE STRATIFIED BY AGE AND OCCUPATION

\begin{tabular}{|c|c|c|c|c|c|c|c|c|c|c|c|}
\hline Occupation & $\underset{\text { Group }}{\text { Age }}$ & $\begin{array}{l}\text { No. in Population } \\
\text { at Census* }\end{array}$ & $\begin{array}{l}\text { No. } \\
\text { Sampled }\end{array}$ & Dead & $\begin{array}{l}\text { Left } \\
\text { Area }\end{array}$ & Refused & $\begin{array}{l}\text { Not } \\
\text { Seen }\end{array}$ & Seen & Excluded $\dagger$ & \begin{tabular}{|l|} 
Added from \\
Other Groups
\end{tabular} & $\begin{array}{c}\text { Finally } \\
\text { Analysed }\end{array}$ \\
\hline Non-miners & $\begin{array}{l}35-44 \\
45-54 \\
55-64\end{array}$ & $\begin{array}{l}495 \\
338 \\
146\end{array}$ & $\begin{array}{l}100 \\
100 \\
100\end{array}$ & $\begin{array}{l}0 \\
1 \\
0\end{array}$ & $\begin{array}{l}6 \\
2 \\
0\end{array}$ & $\begin{array}{l}9 \\
8 \\
9\end{array}$ & $\begin{array}{l}0 \\
1 \\
2\end{array}$ & $\begin{array}{l}85 \\
88 \\
89\end{array}$ & $\begin{array}{l}1 \\
3 \\
4\end{array}$ & $\begin{array}{l}4 \\
3 \\
1\end{array}$ & $\begin{array}{l}88 \\
88 \\
86\end{array}$ \\
\hline $\begin{array}{l}\text { Miners and } \\
\text { ex-miners }\end{array}$ & $\begin{array}{l}35-44 \\
45-54 \\
55-64\end{array}$ & $\begin{array}{l}1,127 \\
1,283 \\
1,114\end{array}$ & $\begin{array}{l}100 \\
100 \\
100\end{array}$ & $\begin{array}{l}\mathbf{0} \\
\mathbf{0} \\
\mathbf{3}\end{array}$ & $\begin{array}{l}2 \\
0 \\
0\end{array}$ & $\begin{array}{l}8 \\
5 \\
4\end{array}$ & $\begin{array}{l}0 \\
0 \\
1\end{array}$ & $\begin{array}{l}90 \\
95 \\
92\end{array}$ & $\begin{array}{l}4 \\
3 \\
1\end{array}$ & $\begin{array}{l}0 \\
3 \\
3\end{array}$ & $\begin{array}{l}86 \\
95 \\
94\end{array}$ \\
\hline Women & $55-64$ & 1,535 & 200 & 4 & 1 & 12 & 8 & 175 & 2 & 0 & 173 \\
\hline
\end{tabular}

* Date of Census June 1, 1958.

† Because age or occupational history was found to be incorrect. 
TABLE 2

MEAN AGE AND MEASUREMENTS

\begin{tabular}{|c|c|c|c|c|c|c|c|c|c|}
\hline \multirow{2}{*}{ Occupation } & \multirow{2}{*}{ Age Group } & \multirow{2}{*}{ No. } & \multirow{2}{*}{$\begin{array}{c}\text { Age } \\
\text { (years) }\end{array}$} & \multicolumn{2}{|c|}{ Standing Height } & \multicolumn{2}{|c|}{ Sitting Height } & \multicolumn{2}{|c|}{ Weight } \\
\hline & & & & in. & cm. & in. & cm. & lb. & kg. \\
\hline Non-miners & $\begin{array}{l}35-44 \\
45-54 \\
55-64\end{array}$ & $\begin{array}{l}88 \\
88 \\
86\end{array}$ & $\begin{array}{l}39 \cdot 5 \\
49 \cdot 7 \\
59.4\end{array}$ & $\begin{array}{l}67 \cdot 1 \\
66 \cdot 7 \\
66 \cdot 4\end{array}$ & $\begin{array}{l}170 \cdot 4 \\
169 \cdot 4 \\
168 \cdot 7\end{array}$ & $\begin{array}{l}35 \cdot 3 \\
35 \cdot 1 \\
34 \cdot 4\end{array}$ & $\begin{array}{l}89 \cdot 7 \\
89 \cdot 2 \\
87 \cdot 4\end{array}$ & $\begin{array}{l}154.7 \\
154.6 \\
148.0\end{array}$ & $\begin{array}{c}70 \cdot 2 \\
70 \cdot 1 \\
67 \cdot 1\end{array}$ \\
\hline $\begin{array}{l}\text { Miners and } \\
\text { ex-miners }\end{array}$ & $\begin{array}{l}35-44 \\
45-54 \\
55-64\end{array}$ & $\begin{array}{l}86 \\
95 \\
94\end{array}$ & $\begin{array}{l}40 \cdot 1 \\
49 \cdot 5 \\
59 \cdot 9\end{array}$ & $\begin{array}{l}67 \cdot 0 \\
65 \cdot 9 \\
65 \cdot 5\end{array}$ & $\begin{array}{l}170 \cdot 2 \\
167.4 \\
166.4\end{array}$ & $\begin{array}{l}35 \cdot 4 \\
34 \cdot 7 \\
34 \cdot 1\end{array}$ & $\begin{array}{l}89 \cdot 9 \\
88 \cdot 1 \\
86.6\end{array}$ & $\begin{array}{l}147 \cdot 7 \\
144 \cdot 2 \\
140 \cdot 1\end{array}$ & $\begin{array}{l}67 \cdot 0 \\
65 \cdot 4 \\
63 \cdot 5\end{array}$ \\
\hline Women & $55-64$ & 173 & $59 \cdot 7$ & 60.9 & $154 \cdot 7$ & $32 \cdot 2$ & $81 \cdot 8$ & $145 \cdot 3$ & 65.9 \\
\hline
\end{tabular}

TABLE 3

PREVALENCE OF PNEUMOCONIOSIS IN THE RHONDDA FACH MINERS AND EX-MINERS IN SAMPLE 1958

\begin{tabular}{|c|c|c|c|c|c|c|c|}
\hline \multirow[b]{2}{*}{ Age Group } & \multicolumn{6}{|c|}{ Radiological Category } & \multirow[b]{2}{*}{ Total } \\
\hline & $\mathbf{0}$ & 1 & 2 & 3 & $\begin{array}{c}\text { All Simple } \\
\text { Pneumoconiosis }\end{array}$ & P.M.F. & \\
\hline
\end{tabular}

Percentages are given in brackets.

TABLE 4

MEAN VENTILATORY CAPACITY MEASUREMENTS IN NON-MINERS, MINERS, AND EX-MINERS ACCORDING TO AGE

\begin{tabular}{|c|c|c|c|c|c|}
\hline Occupation & Age Group & $\underset{\text { (litres/min.) }}{\text { I.M.B.C. }}$ & $\underset{\text { (litres) }}{\text { F.E.V.0.75 }}$ & $\underset{\text { (litres) }}{\text { V.C. }}$ & F.E.V. $\%$ \\
\hline Non-miners & $\begin{array}{l}35-44 \\
45-54 \\
55-64\end{array}$ & $\begin{array}{c}117 \cdot 7 \\
105 \cdot 0 \\
86 \cdot 6^{*}\end{array}$ & $\begin{array}{l}2 \cdot 94 \\
2 \cdot 63 \\
2 \cdot 17\end{array}$ & $\begin{array}{l}4 \cdot 07 \\
3 \cdot 78 \\
3 \cdot 30\end{array}$ & $\begin{array}{l}72 \cdot 7 \\
69 \cdot 8 \\
65 \cdot 4\end{array}$ \\
\hline Miners and ex-miners & $\begin{array}{l}35-44 \\
45-54 \\
55-64\end{array}$ & $\begin{array}{r}109.9 \\
86.7 \\
75.0\end{array}$ & $\begin{array}{l}2 \cdot 75 \\
2 \cdot 17 \\
1 \cdot 88\end{array}$ & $\begin{array}{l}3.95 \\
3.28 \\
2.89\end{array}$ & $\begin{array}{l}68 \cdot 6 \\
64 \cdot 3 \\
63 \cdot 4\end{array}$ \\
\hline
\end{tabular}

* One man excluded.

Prevalence of Pneumoconiosis.-Table 3 shows the prevalence of pneumoconiosis (International Labour Organization, 1953) in each age group in the sample. Categories of simple pneumoconiosis are given separately but all categories of progressive massive fibrosis (P.M.F.) have been combined. Our expectation of equal numbers of men with and without pneumoconiosis in each decade was not realized. In the 35 to 44 age group over half and in the two older age groups nearly three-quarters of the men had radiological changes. The change from the earlier findings (Cochrane et al., 1956) is probably due partly to observer differences in film classification and partly to progression of simple pneumoconiosis during the past six years.
Ventilatory Capacity.-Mean values for the I.M.B.C., F.E.V.0.75, V.C. and F.E.V. \% are shown in Table 4. At all ages miners and ex-miners recorded lower values than non-miners. The differences in the I.M.B.C. are all highly significant $(p<0.01)$ but the differences in the F.E.V. $\%$ are significant only in the two younger age groups. This shows once again the fact, which we have observed previously, that the F.E.V. $\%$ is a less useful test than the F.E.V ${ }_{\mathbf{0 . 7 5}}$ for discriminating between two groups. Only a small part of the difference in means is due to progressive massive fibrosis. If cases with P.M.F. are excluded, the difference in I.M.B.C. of 14 litres per minute in the 45 to 54 and of 10 litres per minute in the 55 to 64 age groups is still statistically significant $(\mathrm{p}<0.01)$. 
TABLE 5

MEAN INDIRECT M.B.C. IN MINERS AND EX-MINERS ACCORDING TO RADIOLOGICAL CATEGORY OF PNEUMOCONIOSIS

\begin{tabular}{|c|c|c|c|c|c|c|}
\hline Age Group & Radiological Category & No. & $\begin{array}{c}\text { I.M.B.C. } \\
\text { (litres/min.) }\end{array}$ & F.E.V.0.075 & $\begin{array}{c}\text { V.C. } \\
\text { (litres) }\end{array}$ & F.E.V. $\%$ \\
\hline $35-44$ & $\begin{array}{l}\text { O } \\
\text { Simple } \\
\text { P.M.F. }\end{array}$ & $\begin{array}{r}36 \\
42 \\
8\end{array}$ & $\begin{array}{r}113.7 \\
112.0 \\
82.0\end{array}$ & $\begin{array}{l}2.84 \\
2.80 \\
2.05\end{array}$ & $\begin{array}{l}4 \cdot 11 \\
4.00 \\
3.03\end{array}$ & $\begin{array}{l}69 \cdot 4 \\
70 \cdot 1 \\
57 \cdot 4\end{array}$ \\
\hline $45-54$ & $\begin{array}{l}\text { O } \\
\text { Simple } \\
\text { P.M.F. }\end{array}$ & $\begin{array}{l}27 \\
41 \\
27\end{array}$ & $\begin{array}{l}85 \cdot 3 \\
94 \cdot 7 \\
76 \cdot 1\end{array}$ & $\begin{array}{l}2 \cdot 13 \\
2 \cdot 37 \\
1 \cdot 90\end{array}$ & $\begin{array}{l}3 \cdot 35 \\
3 \cdot 45 \\
3 \cdot 10\end{array}$ & $\begin{array}{l}62 \cdot 4 \\
68 \cdot 7 \\
59 \cdot 7\end{array}$ \\
\hline
\end{tabular}

While at all ages P.M.F. was associated with a significant reduction in the mean I.M.B.C. at no age did miners with simple pneumoconiosis have significantly lower values than those without (Table 5). Outside this Unit the F.E.V. is usually measured over one second. The correlation between the 0.75 second and 1 second tests is however very high $(r=0.998)$ and the F.E.V.1.0 may be readily obtained from the regression

$$
\text { F.E.V.1.0 }=1.08 \text { F.E.V.0.75 }+0.09 \text { (litres) }
$$

(McKerrow et al., 1960).

Table 6 compares I.M.B.C., F.E.V.0.75 and F.E.V.1.0.

TABLE 6

RELATION BETWEEN INDIRECT M.B.C., F.E.V.0.75, AND F.E.V.1.0

\begin{tabular}{|c|c|c|}
\hline $\begin{array}{c}\text { I.M.B.C. } \\
\text { (litres/min.) }\end{array}$ & $\begin{array}{l}\text { F.E.V.0.75 } \\
\text { (litres) }\end{array}$ & F.E.V.1.0 \\
\hline $\begin{array}{r}10 \\
20 \\
30 \\
40 \\
50 \\
60 \\
70 \\
80 \\
90 \\
100 \\
110 \\
120 \\
130 \\
140 \\
150 \\
160 \\
170 \\
180 \\
190 \\
200\end{array}$ & $\begin{array}{l}0.25 \\
0.50 \\
0.75 \\
1.00 \\
1.25 \\
1.50 \\
1.75 \\
2.00 \\
2.25 \\
2.50 \\
2.75 \\
3.00 \\
3.25 \\
3.50 \\
3.75 \\
4.00 \\
4.25 \\
4.50 \\
4.75 \\
5.00\end{array}$ & $\begin{array}{l}0.36 \\
0.63 \\
0.90 \\
1 \cdot 17 \\
1.44 \\
1 \cdot 71 \\
1.98 \\
2 \cdot 25 \\
2.52 \\
2 \cdot 79 \\
3.06 \\
3.33 \\
3.60 \\
3.87 \\
4 \cdot 14 \\
4.41 \\
4.68 \\
4.95 \\
5.22 \\
5.49\end{array}$ \\
\hline
\end{tabular}

Based on regression:

F.E.V.1.0 $=1.08$ F.E.V.0.7s +0.09 (litres) (McKerrow et al., 1960)

Prevalence of Respiratory Symptoms.-Tables 7 and 8 compare the prevalence of the main symptoms in miners and ex-miners and non-miners and within the mining group according to radiological category of pneumoconiosis. At all ages the miners had between two and three times as high a prevalence of each symptom as the non-miners; but within the mining group symptom prevalence is not closely related to radiological category and no consistent pattern emerges. Men with P.M.F. had a slightly higher prevalence of breathlessness at all ages and rather more chest illness and "chronic bronchitis " in the 35 to 44 and 45 to 54 age groups, but not in the 55 to 64 age groups. Miners and ex-miners with simple pneumoconiosis tended to have a higher prevalence of cough and sputum than those without in the 35 to 44 and 55 to 64 , but not in the 45 to 54 , age groups.

The lower prevalence of all symptoms among the women (Table 9) compared with the appropriate non-mining males, is in line with expectation. The prevalence recorded was however generally higher than that found in the Vale of Glamorgan (Higgins, 1957) and in Annandale (Higgins and Cochran, 1958) and this difference is such as one might expect between town and country.

The prevalence of symptoms and mean I.M.B.C. in the women according to the occupation of their husbands is also shown in Table 9. Wives of miners and ex-miners recorded a higher prevalence of symptoms and a lower ventilatory capacity than the wives of non-miners. It is difficult to draw any far-reaching conclusion from this finding, since there were social class differences between the two groups, for which, with so few non-miners' wives, it was not possible to standardize.

\section{Aetiological Factors}

Mining and Dust Exposure.-We have tried to assess the importance of mining and coal dust exposure by relating respiratory symptoms and the indirect M.B.C. to the length of time spent working on the coal-getting shift (Tables 10 and 11). In the Tables concerned with the indirect M.B.C. the radiological categories of pneumoconiosis are shown separately; but in dealing with the pre- 
TABLE 7

PREVALENCE OF RESPIRATORY SYMPTOMS AND “CHRONIC BRONCHITIS" ACCORDING TO AGE, SEX, AND OCCUPATION IN SAMPLE 1958

\begin{tabular}{|c|c|c|c|c|c|c|c|c|c|c|c|}
\hline \multirow[b]{2}{*}{ Occupation } & \multirow{2}{*}{$\begin{array}{l}\text { Age } \\
\text { Group }\end{array}$} & \multirow[b]{2}{*}{ No. } & \multirow[b]{2}{*}{ Cough } & \multirow[b]{2}{*}{ Sputum } & \multirow{2}{*}{$\begin{array}{l}\text { Cough } \\
\text { and } \\
\text { Sputum }\end{array}$} & \multicolumn{3}{|c|}{ Chest Illness } & \multicolumn{2}{|c|}{ Breathlessness } & \multirow{2}{*}{$\begin{array}{l}\text { "Chronic } \\
\text { Bronchitis" }\end{array}$} \\
\hline & & & & & & Once & $\begin{array}{c}\text { More than } \\
\text { Once }\end{array}$ & Total & $\begin{array}{c}\text { Grade } 2 \\
\text { and Over }\end{array}$ & $\begin{array}{c}\text { Grade } 3 \\
\text { and Over }\end{array}$ & \\
\hline Non-miners & $\begin{array}{l}35-44 \\
45-54 \\
55-64\end{array}$ & $\begin{array}{l}88 \\
88 \\
86\end{array}$ & $\begin{array}{l}33(37 \cdot 5) \\
31(35 \cdot 2) \\
36(41 \cdot 9)\end{array}$ & $\begin{array}{l}30(34 \cdot 1) \\
27(30 \cdot 7) \\
30(34 \cdot 8)\end{array}$ & $\begin{array}{ll}23 & (26 \cdot 1) \\
21 & (23 \cdot 9) \\
25 & (29 \cdot 1)\end{array}$ & 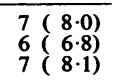 & $\begin{array}{r}2(2 \cdot 3) \\
8(9 \cdot 1) \\
10(11 \cdot 6)\end{array}$ & $\begin{array}{r}9(10 \cdot 2) \\
14(15.9) \\
17(19.8)\end{array}$ & 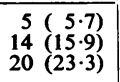 & $\begin{array}{l}3(3 \cdot 4) \\
6(6 \cdot 8) \\
9(10 \cdot 5)\end{array}$ & $\begin{array}{r}4(4 \cdot 5) \\
11(12 \cdot 5) \\
9(10 \cdot 5)\end{array}$ \\
\hline $\begin{array}{l}\text { Miners and } \\
\text { ex-miners }\end{array}$ & $\begin{array}{l}35-44 \\
45-54 \\
55-64\end{array}$ & $\begin{array}{l}86 \\
95 \\
94\end{array}$ & $\begin{array}{l}47(54 \cdot 7) \\
58(61 \cdot 1) \\
60(63 \cdot 8)\end{array}$ & $\begin{array}{l}44(51 \cdot 2) \\
61(64 \cdot 2) \\
60(63 \cdot 8)\end{array}$ & $\begin{array}{ll}34 & (39 \cdot 5) \\
51 & (53 \cdot 7) \\
53 & (56 \cdot 4)\end{array}$ & $\begin{array}{r}7(8 \cdot 1) \\
10(10 \cdot 5) \\
13(13 \cdot 8)\end{array}$ & $\begin{array}{l}15(17 \cdot 4) \\
26(27 \cdot 4) \\
22(23.4)\end{array}$ & $\begin{array}{l}22(25 \cdot 6) \\
36(37 \cdot 9) \\
35(37 \cdot 2)\end{array}$ & $\begin{array}{ll}32 & (37 \cdot 2) \\
49 & (51 \cdot 6) \\
61 & (64 \cdot 9)\end{array}$ & $\begin{array}{ll}11 & (12 \cdot 8) \\
22 & (23 \cdot 2) \\
35 & (37 \cdot 2)\end{array}$ & $\begin{array}{l}16(18 \cdot 6) \\
33(34 \cdot 7) \\
30(31 \cdot 9)\end{array}$ \\
\hline Women & $55-64$ & 173 & $27(15 \cdot 6)$ & $28(16 \cdot 2)$ & $17(9.8)$ & $24(13.9)$ & $15(8 \cdot 7)$ & $39(22 \cdot 5)$ & $61(35 \cdot 3)$ & $27(15 \cdot 6)$ & $12(6.9)$ \\
\hline
\end{tabular}

Percentages in brackets.

* Defined as persistent sputum and at least one chest illness sufficiently severe to keep a man off work for one week during past three years.

TABLE 8

PREVALENCE OF RESPIRATORY SYMPTOMS AND “ CHRONIC BRONCHITIS " IN MINERS ACCORDING TO RADIOLOGICAL CATEGORY OF PNEUMOCONIOSIS

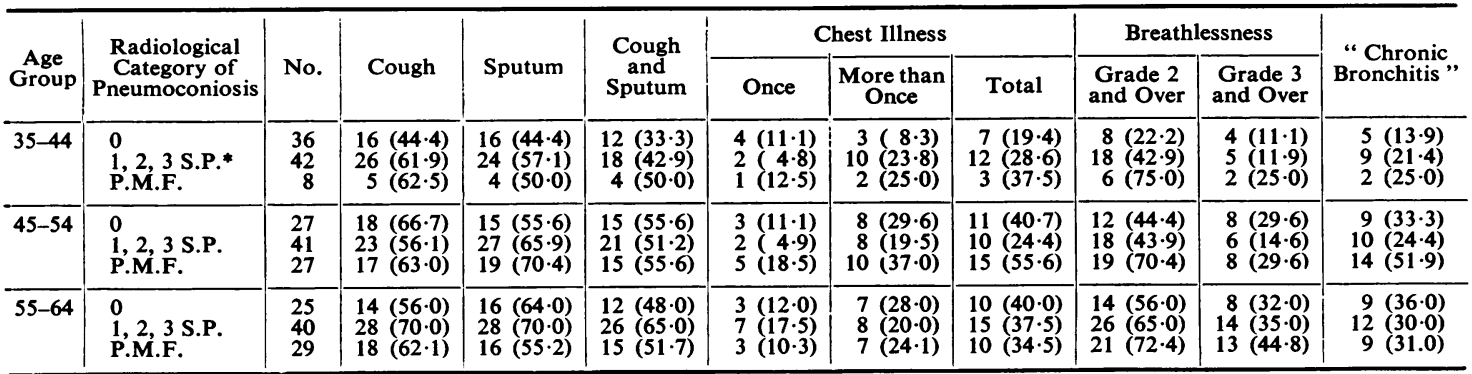

* Simple pneumoconiosis.

Percentages in brackets.

TABLE 9

PREVALENCE OF RESPIRATORY SYMPTOMS AND MEAN I.M.B.C. OF WOMEN ACCORDING TO MARITAL STATUS AND OCCUPATION OF HUSBAND

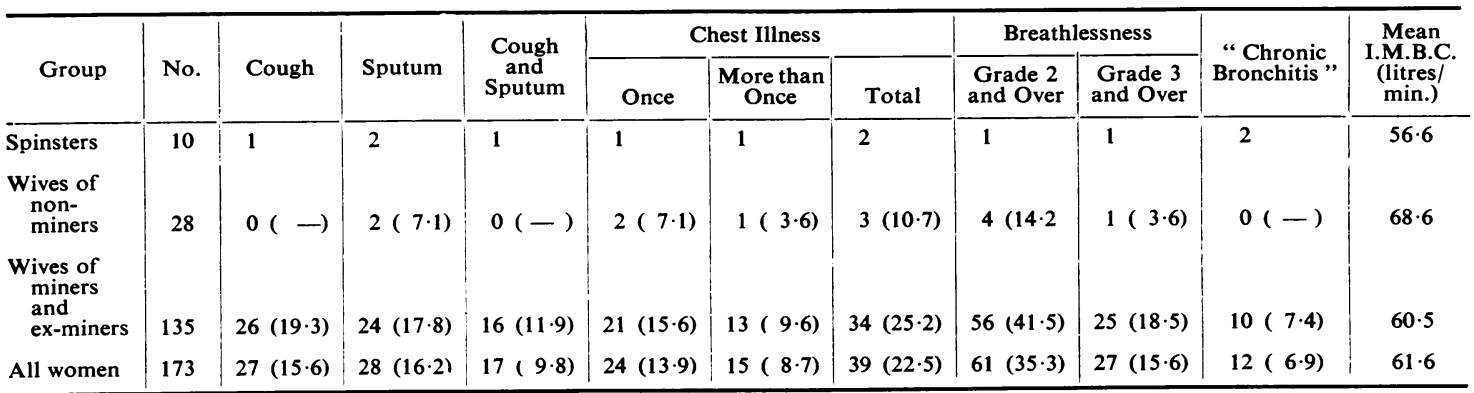

Percentages in brackets.

valence of symptoms this is not possible due to the small numbers. A somewhat higher prevalence of symptoms was observed in those who had worked for more than one year either underground or on the coal-face; but over one year there was no consistent increase in prevalence with increased duration. Similarly the mean I.M.B.C. was higher in those who had worked less than one year, the values closely approximating to those expected for non-miners. There also appears to be an overall downward trend (which does not however reach the $5 \%$ level of statistical significance) in the mean 
TABLE 10

PREVALENCE OF SYMPTOMS ACCORDING TO NUMBER OF YEARS SPENT WORKING ON THE COAL-GETTING SHIFT

\begin{tabular}{|c|c|c|c|c|c|c|c|}
\hline \multirow{2}{*}{ Age Group } & & \multicolumn{5}{|c|}{ Years Spent on Coal-getting Shift } & \multirow[b]{2}{*}{ Total } \\
\hline & & $0-1$ & $1-9$ & $10-19$ & $20-29$ & $30+$ & \\
\hline \multirow[t]{2}{*}{$35-44$} & No. in group & 16 & 46 & 18 & 6 & & 86 \\
\hline & $\begin{array}{l}\text { No. with: } \\
\text { Cough and sputum } \\
\text { Chest illness } \\
\text { Breathlessness } \\
\text { "Chronic bronchitis" }\end{array}$ & $\begin{array}{l}6(37 \cdot 5) \\
2(12 \cdot 5) \\
2(12 \cdot 5) \\
1(6 \cdot 3)\end{array}$ & $\begin{array}{l}18(39 \cdot 1) \\
13(28 \cdot 3) \\
18(39 \cdot 1) \\
12(26 \cdot 1)\end{array}$ & $\begin{array}{l}9(50 \cdot 0) \\
6(33 \cdot 3) \\
9(50 \cdot 0) \\
2(11 \cdot 1)\end{array}$ & $\begin{array}{l}1(16 \cdot 7) \\
1(16 \cdot 7) \\
3(50 \cdot 0) \\
1(16 \cdot 7)\end{array}$ & & $\begin{array}{l}34 \\
22 \\
32 \\
16\end{array}$ \\
\hline \multirow[t]{2}{*}{$45-54$} & No. in group & 6 & 38 & 23 & 25 & 3 & 95 \\
\hline & $\begin{array}{l}\text { No. with: } \\
\text { Cough and sputum } \\
\text { Chest illness } \\
\text { Breathlessness } \\
\text { "Chronic bronchitis" }\end{array}$ & $\begin{array}{l}3(50 \cdot 0) \\
0 \\
1 \\
0\end{array}(16 \cdot 7)$ & $\begin{array}{l}18(47 \cdot 4) \\
16(42 \cdot 1) \\
22(57 \cdot 9) \\
14(36 \cdot 8)\end{array}$ & $\begin{array}{l}15(65 \cdot 2) \\
12(52 \cdot 2) \\
12(52 \cdot 2) \\
11(47 \cdot 8)\end{array}$ & $\begin{array}{r}12(48 \cdot 0) \\
7(28 \cdot 0) \\
12(48 \cdot 0) \\
7(28 \cdot 0)\end{array}$ & $\begin{array}{lr}3 & (100 \cdot 0) \\
1 & (33 \cdot 3) \\
2 & (66 \cdot 7) \\
1 & (33 \cdot 3)\end{array}$ & $\begin{array}{l}51 \\
36 \\
49 \\
33\end{array}$ \\
\hline \multirow[t]{2}{*}{$55-64$} & No. in group & 10 & 33 & 28 & 17 & 6 & 94 \\
\hline & $\begin{array}{l}\text { No. with: } \\
\text { Cough and sputum } \\
\text { Chest illness } \\
\text { Breathlessness } \\
\text { "Chronic bronchitis" }\end{array}$ & $\begin{array}{l}4(40 \cdot 0) \\
2(20 \cdot 0) \\
4(40 \cdot 0) \\
1(10 \cdot 0)\end{array}$ & $\begin{array}{l}17(51 \cdot 5) \\
14(42 \cdot 4) \\
22(66 \cdot 7) \\
12(36 \cdot 4)\end{array}$ & $\begin{array}{r}17(60 \cdot 7) \\
11(39 \cdot 3) \\
18(64 \cdot 3) \\
9(32 \cdot 1)\end{array}$ & $\begin{array}{r}11(64 \cdot 7) \\
7(41 \cdot 2) \\
13(76 \cdot 4) \\
7(41 \cdot 2)\end{array}$ & $\begin{array}{l}4(66 \cdot 7) \\
1(16 \cdot 7) \\
4(66 \cdot 7) \\
1(16 \cdot 7)\end{array}$ & $\begin{array}{l}53 \\
35 \\
61 \\
30\end{array}$ \\
\hline
\end{tabular}

TABLE 11

MEAN I.M.B.C. ACCORDING TO NUMBER OF YEARS SPENT WORKING ON COAL-GETTING SHIFT

\begin{tabular}{|c|c|c|c|c|c|c|c|c|c|}
\hline \multirow{3}{*}{ Age Group } & \multirow{3}{*}{$\begin{array}{l}\text { Radiological Category } \\
\text { of Pneumoconiosis }\end{array}$} & \multicolumn{8}{|c|}{ Years Spent on Coal-getting Shift } \\
\hline & & \multicolumn{2}{|c|}{$<1$} & \multicolumn{2}{|c|}{$1-9$} & \multicolumn{2}{|c|}{$10-19$} & \multicolumn{2}{|c|}{20 and over } \\
\hline & & No. & I.M.B.C. & No. & I.M.B.C. & No. & I.M.B.C. & No. & I.M.B.C. \\
\hline \multirow[t]{2}{*}{$35-44$} & $\begin{array}{l}\mathbf{0} \\
\text { 1, } 2,3 \\
\text { P.M.F. }\end{array}$ & 16 & $112 \cdot 3$ & $\begin{array}{r}19 \\
25 \\
2\end{array}$ & $\begin{array}{r}115.1 \\
114.0 \\
78.0\end{array}$ & $\begin{array}{r}1 \\
11 \\
6\end{array}$ & $\begin{array}{r}109 \cdot 0 \\
112.9 \\
83 \cdot 3\end{array}$ & $\begin{array}{l}0 \\
6 \\
0\end{array}$ & $\overline{102 \cdot 2}$ \\
\hline & All & 16 & $112 \cdot 3$ & 46 & $112 \cdot 9$ & 18 & $102 \cdot 8$ & 6 & $102 \cdot 2$ \\
\hline \multirow[t]{2}{*}{$45-54$} & $\begin{array}{l}\mathbf{0} \\
\text { 1, 2, } 3 \\
\text { P.M.F. }\end{array}$ & 6 & $111 \cdot 8$ & $\begin{array}{r}15 \\
18 \\
5\end{array}$ & $\begin{array}{l}78 \cdot 2 \\
96 \cdot 0 \\
92 \cdot 8\end{array}$ & $\begin{array}{r}4 \\
11 \\
8\end{array}$ & $\begin{array}{l}76 \cdot 0 \\
98 \cdot 1 \\
61 \cdot 0\end{array}$ & $\begin{array}{r}2 \\
12 \\
14\end{array}$ & $\begin{array}{l}78 \cdot 0 \\
89 \cdot 5 \\
78 \cdot 8\end{array}$ \\
\hline & All & 6 & $111 \cdot 8$ & 38 & $88 \cdot 6$ & 23 & $81 \cdot 3$ & 28 & $83 \cdot 3$ \\
\hline \multirow[t]{2}{*}{$55-64$} & $\begin{array}{l}\mathbf{0} \\
\mathbf{1}, 2,3 \\
\text { P.M.F. }\end{array}$ & $\begin{array}{l}3 \\
5 \\
2\end{array}$ & $\begin{array}{l}92 \cdot 3 \\
95 \cdot 2 \\
71 \cdot 5\end{array}$ & $\begin{array}{r}16 \\
13 \\
4\end{array}$ & $\begin{array}{l}79 \cdot 8 \\
71 \cdot 2 \\
71 \cdot 5\end{array}$ & $\begin{array}{r}3 \\
18 \\
7\end{array}$ & $\begin{array}{l}43 \cdot 3 \\
79 \cdot 7 \\
66 \cdot 6\end{array}$ & $\begin{array}{r}3 \\
4 \\
16\end{array}$ & $\begin{array}{l}81 \cdot 7 \\
56 \cdot 0 \\
73 \cdot 1\end{array}$ \\
\hline & All & 10 & $89 \cdot 5$ & 33 & 75.4 & 28 & $72 \cdot 5$ & 23 & $71 \cdot 3$ \\
\hline
\end{tabular}

I.M.B.C. with time spent on the coal-getting shift. The analysis by radiological category of pneumoconiosis suggests that this is more obvious in the men without pneumoconiosis and in those with P.M.F. and that it does not occur in those with simple pneumoconiosis. This is in line with other observations (Cochrane and Higgins, 1961) and might possibly be explained in part by the loss of cases of simple pneumoconiosis with lower I.M.B.C.'s into the P.M.F. group.

If inhaling coal-mine dust does depress lung function we might expect improvement to occur when a man leaves mining and is no longer exposed to coal dust. By including ex-miners in our analysis we might possibly have concealed some of the effect of the dust dose. We have therefore repeated the analysis for miners and ex-miners separately (Table 12). This certainly suggests, at least in the 55 to 64 age group, that the decline in ventilatory capacity with increasing years spent working on the coal-face is greater in the working miners and therefore supports Worth, Gasthaus, Lühning, Muysers, Siehoff, and Werner (1959) who showed a fall in ventilatory function with duration of underground work in a large group of working miners from the left lower Rhine. A decline in lung function with increasing time spent working underground was also recorded in miners attending hospital by Carstens, Brinkmann, Lange, Meisterernst, and Schlicht (1958). 
Tobacco Smoking.-Smoking habits were recorded as in our previous studies in the way originally advocated by Doll and Bradford Hill (1950). The current smoking groups were then combined into light (1-14 g. tobacco per day) and heavy (15 g. and over per day). The results for the three age groups when analysed separately indicated a similar conclusion to that found when they were combined. For simplicity and brevity therefore Table 13 shows the analysis for all ages.

There was a higher proportion of non-smokers among the non-miners and more of the miners and ex-miners were light smokers. These findings support previous observations (Cross, McDowell, and Posner, 1958). Differences in prevalence of respiratory symptoms and I.M.B.C. between miners and non-miners are still obvious after standardizing for tobacco smoking. With the exception of breathlessness, current smokers had a higher prevalence of symptoms than either non-smokers or ex-smokers. This is more obvious in the mining group. The non-smokers recorded a higher mean I.M.B.C. than the smokers and ex-smokers, though in the case of the mining group the difference is not large. These findings in regard to tobacco smoking are in agreement with previous results in other areas but are rather less striking than our observations in Staveley.

Among the women the prevalence of symptoms was higher in smokers than in non-smokers; but

TABLE 12

MEAN I.M.B.C. ACCORDING TO NUMBER OF YEARS SPENT WORKING ON COAL-GETTING SHIFT

\begin{tabular}{|c|c|c|c|c|c|c|c|c|c|c|c|c|c|}
\hline \multirow{3}{*}{ Age } & \multirow{3}{*}{ Occupation } & \multicolumn{10}{|c|}{ Years Spent on Coal-getting Shift } & \multirow{2}{*}{\multicolumn{2}{|c|}{ Total }} \\
\hline & & \multicolumn{2}{|r|}{$<1$} & \multicolumn{2}{|r|}{$1-9$} & \multicolumn{2}{|c|}{$10-19$} & \multicolumn{2}{|c|}{$20-29$} & \multicolumn{2}{|c|}{30 and over } & & \\
\hline & & No & I.M.B.C. & No. & I.M.B.C. & No. & I.M.B.C. & No. & I.M.B.C. & No. & I.M.B.C. & No. & I.M.B.C. \\
\hline \multirow[t]{2}{*}{$35-44$} & $\begin{array}{l}\text { Miners } \\
\text { Ex-miners }\end{array}$ & $\begin{array}{r}12 \\
4\end{array}$ & $\begin{array}{l}111.2 \\
115.8\end{array}$ & $\begin{array}{l}23 \\
23\end{array}$ & $\begin{array}{l}119.0 \\
106.8\end{array}$ & $\begin{array}{r}10 \\
8\end{array}$ & $\begin{array}{r}105.9 \\
99.0\end{array}$ & $\begin{array}{l}6 \\
0\end{array}$ & $102 \cdot 2$ & $\begin{array}{l}0 \\
0\end{array}$ & $=$ & $\begin{array}{l}51 \\
35\end{array}$ & $\begin{array}{l}112.6 \\
106.0\end{array}$ \\
\hline & Both & 16 & $112 \cdot 3$ & 46 & $112 \cdot 9$ & 18 & $102 \cdot 8$ & 6 & $102 \cdot 2$ & 0 & - & 86 & $109 \cdot 9$ \\
\hline \multirow[t]{2}{*}{$45-54$} & $\begin{array}{l}\text { Miners } \\
\text { Ex-miners }\end{array}$ & $\begin{array}{l}4 \\
2 \\
\end{array}$ & $\begin{array}{r}119.8 \\
96.0\end{array}$ & $\begin{array}{l}17 \\
21\end{array}$ & $\begin{array}{l}94.8 \\
83.5\end{array}$ & $\begin{array}{l}11 \\
12\end{array}$ & $\begin{array}{l}91.9 \\
71.7\end{array}$ & $\begin{array}{r}18 \\
7\end{array}$ & $\begin{array}{l}87 \cdot 2 \\
78 \cdot 1\end{array}$ & $\begin{array}{l}1 \\
2\end{array}$ & $\begin{array}{r}112.0 \\
52.0\end{array}$ & $\begin{array}{l}50 \\
45\end{array}$ & $\begin{array}{l}94 \cdot 1 \\
78 \cdot 6\end{array}$ \\
\hline & Both & 6 & $111 \cdot 8$ & 38 & $88 \cdot 6$ & 23 & $81 \cdot 3$ & 25 & $84 \cdot 7$ & 3 & $72 \cdot 0$ & 95 & $86 \cdot 7$ \\
\hline \multirow[t]{2}{*}{$55-64$} & $\begin{array}{l}\text { Miners } \\
\text { Ex-miners }\end{array}$ & $\begin{array}{l}5 \\
5\end{array}$ & $\begin{array}{l}92 \cdot 2 \\
87.0\end{array}$ & $\begin{array}{l}12 \\
21\end{array}$ & $\begin{array}{l}81.4 \\
72.0\end{array}$ & $\begin{array}{r}9 \\
19\end{array}$ & $\begin{array}{l}70 \cdot 7 \\
73 \cdot 4\end{array}$ & $\begin{array}{l}8 \\
9\end{array}$ & $\begin{array}{l}64 \cdot 6 \\
73 \cdot 2\end{array}$ & $\begin{array}{l}3 \\
3\end{array}$ & $\begin{array}{l}71 \cdot 0 \\
83 \cdot 3\end{array}$ & $\begin{array}{l}37 \\
57\end{array}$ & $\begin{array}{l}75.8 \\
74.6\end{array}$ \\
\hline & Both & 10 & $89 \cdot 6$ & 23 & 75.4 & 28 & $72 \cdot 5$ & 17 & $69 \cdot 2$ & 6 & $77 \cdot 2$ & 94 & $75 \cdot 0$ \\
\hline
\end{tabular}

TABLE 13

PREVALENCE OF SYMPTOMS AND MEAN I.M.B.C. ACCORDING TO SMOKING HABITS IN MEN OF ALL AGES

\begin{tabular}{|c|c|c|c|c|c|c|}
\hline \multirow[b]{2}{*}{ Occupation } & & \multirow[b]{2}{*}{ Non-smokers } & \multicolumn{2}{|c|}{ Smokers } & \multirow[b]{2}{*}{ Ex-smokers } & \multirow[b]{2}{*}{ Total } \\
\hline & & & $\begin{array}{c}\text { Light } \\
(1-14 \text { g./day) }\end{array}$ & $\begin{array}{c}\text { Heavy } \\
\text { (15 g./day and over) }\end{array}$ & & \\
\hline \multirow[t]{4}{*}{ Non-miners } & Number & $33(12 \cdot 6)$ & $94(35 \cdot 9)$ & $97(37 \cdot 0)$ & $38(14 \cdot 5)$ & $262(100 \cdot 0)$ \\
\hline & $\begin{array}{l}\text { Those with: } \\
\text { Persistent cough and sputum } \\
\text { Chest illness } \\
\text { Breathlessness }\end{array}$ & $\begin{array}{l}5(15 \cdot 2) \\
4(12 \cdot 2)\end{array}$ & $\begin{array}{l}19(20 \cdot 2) \\
14(14 \cdot 9)\end{array}$ & $\begin{array}{l}41(42 \cdot 3) \\
15(15 \cdot 5)\end{array}$ & $\begin{array}{l}4(10 \cdot 5) \\
7(18 \cdot 4)\end{array}$ & \\
\hline & " (Grade 2 and over) & $\begin{array}{l}5(15 \cdot 2) \\
3(9 \cdot 1)\end{array}$ & $\begin{array}{r}11(11 \cdot 7) \\
9(9 \cdot 6)\end{array}$ & $\begin{aligned} 17(17 \cdot 5) \\
8(8.2)\end{aligned}$ & $\begin{array}{l}6(15 \cdot 7) \\
4(10 \cdot 5)\end{array}$ & \\
\hline & Mean M.B.C. & $114 \cdot 6$ & $104 \cdot 1$ & $99 \cdot 4$ & $105 \cdot 9$ & \\
\hline \multirow{4}{*}{$\begin{array}{l}\text { Miners and } \\
\text { ex-miners }\end{array}$} & Number & $15(5 \cdot 5)$ & $135(49 \cdot 1)$ & $82(29 \cdot 8)$ & $43(15 \cdot 6)$ & $275(100 \cdot 0)$ \\
\hline & $\begin{array}{l}\text { Those with: } \\
\text { Persistent cough and sputum } \\
\text { Chest illness }\end{array}$ & $\begin{array}{l}3(20 \cdot 0) \\
4(26 \cdot 7)\end{array}$ & $\begin{array}{l}71(52 \cdot 6) \\
47(34 \cdot 8)\end{array}$ & $\begin{array}{l}51(62 \cdot 2) \\
32(39 \cdot 0)\end{array}$ & $\begin{array}{l}13(30 \cdot 2) \\
10(23 \cdot 3)\end{array}$ & \\
\hline & $\begin{array}{l}\text { Breatriessness } \\
\text { “ (Grade } 2 \text { and over) }\end{array}$ & $\begin{array}{l}7(46 \cdot 7) \\
2(13 \cdot 3)\end{array}$ & $\begin{array}{l}73(54 \cdot 1) \\
42(31 \cdot 1)\end{array}$ & $\begin{array}{l}39(47 \cdot 6) \\
28(34 \cdot 1)\end{array}$ & $\begin{array}{r}23(53 \cdot 5) \\
7(16 \cdot 3)\end{array}$ & \\
\hline & Mean M.B.C. & $93 \cdot 1$ & $89 \cdot 0$ & $88 \cdot 3$ & $93 \cdot 6$ & \\
\hline
\end{tabular}

Percentages are in brackets. 
smokers recorded a higher mean I.M.B.C. (Table 14). A possible explanation of this anomalous finding might be that women with high I.M.B.C. values are more likely to take up smoking.

\section{Discussion}

The present findings support our earlier observations in the Rhondda Fach (Carpenter et al., 1956; Cochrane, 1958; Higgins, 1960) that miners and ex-miners living there have more chronic non-specific respiratory disease than non-miners. Similar findings in Leigh and Staveley (Higgins et al., $1956 ; 1959)$ together with the national mortality rates (Registrar-General, 1958) permit the conclusion that this excess of respiratory disease is general among the mining community.

In our earlier study in the Rhondda we compared the ventilatory capacity of miners and ex-miners without pneumoconiosis with those with Category 3 simple pneumoconiosis. We found little difference in mean I.M.B.C. between the two groups in men in the 25 to 34 age group, but in the 55 to 64 age group miners and ex-miners without pneumoconiosis recorded a lower mean I.M.B.C. than the men with Category 3 simple pneumoconiosis and this lower value was associated with a bimodal frequency distribution. The difference between the two groups however did not quite reach the $5 \%$ significance level and we were uncertain of the true meaning of the finding. As there was no significant difference in mean I.M.B.C. between those with and those without simple pneumoconiosis in this survey, it is likely that the earlier finding was due to sampling error rather than to the existence of a cohort, in which the proportion of disabled men was unduly high.

TABLE 14

PREVALENCE OF SYMPTOMS AND MEAN I.M.B.C ACCORDING TO SMOKING HABITS IN WOMEN AGED 55 TO 64

\begin{tabular}{|c|c|c|c|c|}
\hline & \multirow{2}{*}{ Non-smokers } & \multicolumn{2}{|c|}{ Smokers } & \multirow{2}{*}{ Ex-smokers } \\
\hline & & Light (1-14 g./day) & Heavy (15 g./day and over) & \\
\hline Number & 141 & 27 & 2 & 3 \\
\hline $\begin{array}{l}\text { Those with: } \\
\text { Persistent cough and sputum } \\
\text { Chest illness } \\
\text { Breathlessness (Grade } 2 \text { and over) } \\
\text { "Chronic bronchitis" }\end{array}$ & $\begin{array}{r}9(6 \cdot 4) \\
30(21 \cdot 3) \\
51(36 \cdot 2) \\
8(5 \cdot 7)\end{array}$ & $\begin{array}{l}6(22 \cdot 2) \\
8(29 \cdot 6) \\
9(33 \cdot 3) \\
3(11 \cdot 1)\end{array}$ & $\begin{array}{l}1 \\
1 \\
1 \\
1\end{array}$ & $\begin{array}{l}1 \\
0 \\
0 \\
0\end{array}$ \\
\hline Mean I.M.B.C. & $50 \cdot 6$ & $59 \cdot 0$ & $76 \cdot 5$ & $88 \cdot 3$ \\
\hline
\end{tabular}

Percentages are in brackets.

TABLE 15

PREVALENCE OF RESPIRATORY SYMPTOMS AND MEAN I.M.B.C. IN MEN AGED 55-64 IN RANDOM SAMPLES OF THE POPULATIG

\begin{tabular}{|c|c|c|c|c|c|c|c|c|c|c|c|c|c|c|}
\hline \multirow{4}{*}{$\begin{array}{l}\text { Area } \\
\text { Occupation } \\
\begin{array}{c}\text { Radiological } \\
\text { Category }\end{array}\end{array}$} & \multirow{4}{*}{\begin{tabular}{|c|}
$\begin{array}{c}\text { Rural } \\
\text { Denmark }\end{array}$ \\
$\begin{array}{c}\text { Born- } \\
\text { holm* }\end{array}$ \\
$\begin{array}{l}\text { Non- } \\
\text { dusty }\end{array}$ \\
\end{tabular}} & \multicolumn{2}{|c|}{$\begin{array}{l}\text { Rural Scotland } \\
\text { and Wales }\end{array}$} & \multicolumn{11}{|c|}{ Urban England and Wales } \\
\hline & & \multirow{2}{*}{$\begin{array}{c}\begin{array}{c}\text { Annan- } \\
\text { dale }\end{array} \\
\begin{array}{l}\text { Non- } \\
\text { dusty }\end{array}\end{array}$} & \multirow{2}{*}{\begin{tabular}{|c|}
$\begin{array}{l}\text { Vale of } \\
\text { Glam- } \\
\text { organ }\end{array}$ \\
$\begin{array}{l}\text { Non- } \\
\text { dusty }\end{array}$
\end{tabular}} & \multicolumn{3}{|c|}{ Leigh } & \multicolumn{5}{|c|}{ Staveley } & \multicolumn{3}{|c|}{ Rhondda Fach $\frac{3}{2}$. } \\
\hline & & & & \multirow[t]{2}{*}{$\begin{array}{c}\text { Non- } \\
\text { miners }\end{array}$} & \multicolumn{2}{|c|}{$\begin{array}{l}\text { Miners and } \\
\text { Ex-miners }\end{array}$} & \multirow[t]{2}{*}{$\begin{array}{l}\text { Non- } \\
\text { dusty }\end{array}$} & \multicolumn{2}{|c|}{$\begin{array}{l}\text { Miners and } \\
\text { Ex-miners }\end{array}$} & \multicolumn{2}{|c|}{$\begin{array}{l}\text { Foundry and Ex- } \\
\text { foundry Workers }\end{array}$} & \multirow[t]{2}{*}{$\begin{array}{l}\text { Non- } \\
\text { miners }\end{array}$} & \multicolumn{2}{|c|}{$\underset{\text { Ex-miners }}{\text { Miners an } \bar{B}}$} \\
\hline & & & & & 0 & \begin{tabular}{|l|} 
Simple \\
Pneumo- \\
coniosis
\end{tabular} & & 0 & $\begin{array}{l}\text { Simple } \\
\text { Pneumo- } \\
\text { coniosis }\end{array}$ & 0 & \begin{tabular}{|l|} 
Simple \\
Pneumo- \\
coniosis
\end{tabular} & & 0 & $\begin{array}{l}\text { Simple } \\
\text { Pnewitno- } \\
\text { contsis is }\end{array}$ \\
\hline No. in sample & 156 & 87 & 86 & 84 & 101 & 21 & 81 & 96 & 53 & 50 & 14 & 86 & 25 & $40 N$ \\
\hline $\begin{array}{l}\text { No. with: } \\
\text { Persistent cough } \\
\text { and sputum } \\
\text { Chest illness }\end{array}$ & $14(9 \cdot 0)$ & $17(19 \cdot 5)$ & $22(25 \cdot 6)$ & $15(17.9)$ & $38(37 \cdot 6)$ & $4(19 \cdot 0)$ & $26(32 \cdot 1)$ & $38(39 \cdot 6)$ & $20(37 \cdot 7)$ & $15(30 \cdot 0)$ & $5(35 \cdot 7)$ & $25(29 \cdot 1)$ & $12(48 \cdot 0)$ & 26 (2) \\
\hline $\begin{array}{l}\text { Once } \\
\text { More than once } \\
\text { Total } \\
\text { Breathlessness }\end{array}$ & $\left|\begin{array}{r}10(6.4) \\
0\left(\frac{6}{6}\right) \\
10\left(\frac{6.4}{)}\right.\end{array}\right|$ & $\begin{array}{r}12(13 \cdot 8) \\
4(4 \cdot 6) \\
16(18 \cdot 3)\end{array} \mid$ & $\begin{array}{r}10(11 \cdot 6) \\
4(4 \cdot 7) \\
14(16 \cdot 3)\end{array}$ & $\begin{array}{r}6(7 \cdot 1) \\
11(13 \cdot 1) \\
17(20 \cdot 2)\end{array}$ & $\begin{array}{r}9(8.9) \\
23(22 \cdot 8) \\
32(31 \cdot 7)\end{array}$ & $\begin{array}{l}3(14 \cdot 3) \\
4(19 \cdot 0) \\
7(33 \cdot 3)\end{array}$ & $\begin{array}{r}7(8 \cdot 6) \\
10(12 \cdot 3) \\
17(21 \cdot 0)\end{array}$ & $\begin{array}{l}12(12 \cdot 5) \\
15(15 \cdot 6) \\
27(28 \cdot 1)\end{array}$ & $\begin{array}{r}2(3 \cdot 8) \\
12(22 \cdot 6) \\
14(26 \cdot 4)\end{array}$ & $\begin{array}{l}4(8.0) \\
4(8.0) \\
8(16.0)\end{array}$ & $\begin{array}{l}0(\overline{7}) \\
1(7 \cdot 1) \\
1(7 \cdot 1)\end{array}$ & $\begin{array}{r}7(8 \cdot 1) \\
10(11 \cdot 6) \\
17(19 \cdot 8)\end{array}$ & $\begin{array}{r}3(12.0) \\
7(28.0) \\
10(40.0)\end{array}$ & $\begin{array}{r}7(17 \cdot 5) \\
8(25 \cdot 0) \\
15 \text { (37.5) }\end{array}$ \\
\hline $\begin{array}{l}\text { Grades } 2 \text { and } \\
\text { over } \\
\text { Grades } 3 \text { and }\end{array}$ & $25(16 \cdot 0)$ & $25(28 \cdot 7)$ & $21(24 \cdot 4)$ & $19(22 \cdot 6)$ & $37(36 \cdot 6)$ & $8(38 \cdot 1)$ & $27(33 \cdot 3)$ & $31(32 \cdot 3)$ & $25(47 \cdot 2)$ & $22(44 \cdot 0)$ & $4(28 \cdot 6)$ & $20(23 \cdot 3)$ & $14(56 \cdot 0)$ & 26 (被.00) \\
\hline $\begin{array}{l}\text { over } \\
\text { "Chronic }\end{array}$ & $7(4 \cdot 5)$ & $8(9 \cdot 2)$ & $7(7 \cdot 9)$ & $6(7 \cdot 2)$ & $25(24 \cdot 8)$ & $2(9 \cdot 5)$ & $9(11 \cdot 1)$ & $8(8 \cdot 3)$ & $9(17 \cdot 0)$ & $7(14 \cdot 0)$ & $2(14 \cdot 2)$ & $9(10 \cdot 5)$ & $8(32 \cdot 0)$ & $14(\underset{7}{35} 0)$ \\
\hline $\begin{array}{c}\text { bronchitis " } \\
\text { Mean I.M.B.C. }\end{array}$ & $406(2 \cdot 6)$ & $65(6.9)$ & $\left|\begin{array}{c}5(5 \cdot 8) \\
89\end{array}\right|$ & $\mid 95(10 \cdot 7)$ & $\begin{array}{l}27(26 \cdot 7) \\
76\end{array}$ & ${ }_{85}^{3(14 \cdot 3)}$ & $\begin{array}{l}12(14 \cdot 8) \\
90\end{array}$ & $\begin{array}{l}18(18 \cdot 8) \\
87\end{array}$ & $\begin{array}{l}13(24 \cdot 5) \\
87\end{array}$ & \begin{tabular}{|l}
$5(10 \cdot 0)$ \\
85
\end{tabular} & $\mid \begin{array}{c}0 \\
82\end{array}$ & $\begin{array}{l}9(10 \cdot 5) \\
87\end{array}$ & $97(36 \cdot 0)$ & 12 (\$).0) \\
\hline $\begin{array}{l}\text { Perce } \\
{ }^{*} \text { Ols }\end{array}$ & $\begin{array}{l}\text { ntages are } \\
\mathrm{n} \text { and } \mathrm{Gil}\end{array}$ & $\begin{array}{l}\text { in bracket } \\
\text { on }(1960)\end{array}$ & & & & & & & & & & & & 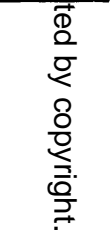 \\
\hline
\end{tabular}


TABLE 16

PREVALENCE OF RESPIRATORY SYMPTOMS AND I.M.B.C. ACCORDING TO LENGTH OF TIME SPENT ON COAL-GETTING SHIFT: MINERS AND EX-MINERS AGED 55-64 SEEN IN LEIGH

\begin{tabular}{|c|c|c|c|c|c|c|}
\hline & \multicolumn{6}{|c|}{ Years Spent on Coal-getting Shift } \\
\hline & 1 & $1-9$ & $10-19$ & $20-29$ & $30-39$ & $40+$ \\
\hline All in the sample & 40 & 18 & 33 & 28 & 10 & 3 \\
\hline $\begin{array}{l}\text { Those with: } \\
\text { Cough and sputum } \\
\text { Chest illness } \\
\text { Breathlessness } \\
\text { "Chronic bronchitis" }\end{array}$ & $\begin{array}{l}10(25 \cdot 0) \\
13(32 \cdot 5) \\
16(40 \cdot 0) \\
10(25 \cdot 0)\end{array}$ & $\begin{array}{l}5(27 \cdot 8) \\
5(27 \cdot 8) \\
6(33 \cdot 3) \\
3(16 \cdot 7)\end{array}$ & $\begin{array}{r}16(48 \cdot 5) \\
9(27 \cdot 3) \\
10(30 \cdot 3) \\
7(21 \cdot 2)\end{array}$ & $\begin{array}{l}12(42 \cdot 9) \\
12(42 \cdot 9) \\
12(42 \cdot 9) \\
10(35 \cdot 7)\end{array}$ & $\begin{array}{l}3(30 \cdot 0) \\
3(30 \cdot 0) \\
4(40 \cdot 0) \\
1(10 \cdot 0)\end{array}$ & $\begin{array}{l}0(-) \\
0(-) \\
1(33 \cdot 3) \\
0(-)\end{array}$ \\
\hline I.M.B.C. & 78.9 & $79 \cdot 8$ & $80 \cdot 4$ & $69 \cdot 3$ & $75 \cdot 2$ & $87 \cdot 7$ \\
\hline
\end{tabular}

Percentages are in brackets

Regional Differences.-One of the striking findings in our comparisons of miners and non-miners in different areas has been that there are considerable regional differences in the amount of chronic non-specific respiratory disease among miners. Table 15 shows that with the exception of persistent cough and sputum, which appeared surprisingly uncommon in Leigh, non-miners recorded a similar prevalence of symptoms and similar mean I.M.B.C. in each of the three areas. But whereas in Staveley the miners and ex-miners had only a slightly higher prevalence of symptoms and an insignificantly lower I.M.B.C. than the corresponding group of nonminers in the Rhondda Fach the differences between them were much greater.

Cause of the Occupational Difference.-We cannot attribute the difference in the amount of chronic respiratory disease between non-miners and miners and ex-miners to different degrees of exposure to general atmospheric pollution. For the miner, while working underground, is spared the vagaries of the British climate and so is less exposed to fog and "smog" than others. Nor do differences in tobacco consumption between miners and nonminers explain the finding. In Leigh the smoking habits of mining and non-mining groups were remarkably similar and in the present survey the occupational difference is still apparent after standardizing for tobacco consumption. Genetic differences leading to increased susceptibility, though of possible importance in the aetiology of bronchitis in general, are unlikely to affect only the miners.

Social class differences are however perhaps more important. The gradient in the mortality rates from bronchitis with social class has long been a striking feature of the national statistics. In the Rhondda Fach there are certainly differences in social class between the two occupational groups and these class differences are particularly evident in the older men, the professional classes being exceptionally highly represented among the non-miners. Exclusion of classes I and II from the non-miners does not however abolish the respiratory disease difference between them and the miners. The lower mean I.M.B.C. and higher prevalence of respiratory symptoms in the wives of miners and ex-miners provide some further support for a social factor accounting for some of the difference between miners and non-miners.

Exposure to dust at work is widely believed to be an important cause of bronchitis and it is surprising therefore how difficult it has proved in our surveys to show any very close relation between dust dosage and either symptom prevalence or lung function in all miners and ex-miners in the area. It is of course possible that the relation one might expect is concealed because those affected by dust move either to less dusty jobs within the industry or to jobs outside mining, with the result that those who have worked for the longer periods either undergound or on the coal-face will tend to be the fitter survivors. It is interesting in this connexion that Becklake, Zwi, and Lutz (1959) found no relationship between respiratory symptoms and dust exposure in Witwatersrand gold-miners without radiological silicosis. These authors also recorded that exercise capacity appeared best in those men whose dust dosage was highest. It is possible, as the present findings suggest, that including ex-miners may lead to an effect of dust on lung function being underestimated. On the other hand we were unable to improve the rather unconvincing effect of dust dosage on symptoms and I.M.B.C. in our Leigh survey (Table 16) by analysing miners and ex-miners separately. If dust were as important as is often thought one would have expected that the miners with simple pneumoconiosis, who have been exposed to a larger average dose of coal dust during their working lives, would have been more affected by bronchitis and disability than the miners without such radiological changes. Our findings suggest that there is little difference between them. 
Short-term studies before and after the shift carried out at this unit have supported the observations of Pestiaux, Gielen, Degueldre, and Lavenne (1955) and Worth, Valentin, Gasthaus, Hoffman, and Venrath (1955) that there is no reduction in ventilatory capacity during the course of a single shift. Furthermore, preliminary observations on new entrants into mines in the Rhondda suggest that the ventilatory capacity is little affected by present dust levels though these are probably now much lower than they were in the past.

Other factors in mining might be responsible for the difference between miners and non-miners. Miners are for example engaged in heavy work, exposed to fumes underground during shot firing, and liable to changes of temperature during their day's work. We have no evidence to incriminate any of these factors, which are in any case not confined to mining. Possibly further light may be thrown on this subject by the National Coal Board's Field Research scheme and by follow-up studies of various population samples already studied, some of which are already being undertaken. At present it seems reasonable to conclude that while exposure to coal dust is one of the factors causing chronic non-specific respiratory disease it is unlikely to explain all the difference in this respect between miners and the rest of the community.

Cause of the Regional Difference.-While it is hard to explain the difference in chronic respiratory disease between miners and non-miners adequately it is even harder to explain the difference between miners in the Rhondda Fach and in Staveley. Briefly there are three possibilities. The difference could be due to variations either in the quantity or in the quality of the coal-mine dust in the two places; or, it might be due to differences in the amount of occupational selection occurring in them or, to differences in the amount of migration into and out of the areas. We have unfortunately insufficient information on any of these points to do more than speculate. Cochrane (1958) related the prevalence of simple pneumoconiosis in miners in Staveley to the length of time they had worked on the coal-face and concluded that the concentration of dust in Staveley mines was unlikely to have been greatly different from that in the Rhondda mines. Miners in Staveley tended to go on the coal-face some five years later than they did in the Rhondda and, consequently, had a somewhat shorter period of dust exposure. Cochrane however concluded that quantitative differences between the two areas could not explain the differences in ventilatory capacity. The possible importance of the age of entry into mining was considered by Worth et al.
(1959). Their results suggested that differences in residual and functional residual volume between miners and non-mining controls were larger in those entering mining early in life. The early age at which the Rhondda miners started work on the coal-face might therefore be a contributory factor in the regional difference in respiratory disease.

There are certainly qualitative differences in the dust in the two areas, the coal of the Rhondda being of higher rank than that of Staveley. No evidence of differences in the morbid anatomy of miners' lungs in the two areas has yet been produced. Most comparisons have been concerned mainly with the more specific changes of pneumoconiosis and it might be useful to compare the lungs from the point of view of bronchitis and emphysema.

The hypothesis that emigration of the fitter members of the mining community from the Rhondda during the 1920's and 1930's has depleted the cohort of men who are now between the ages of 55 and 64 and has left us with a group with a lower lung function is considered in detail elsewhere (Cochrane and Higgins, 1961).

We should like to thank our colleagues at the Pneumoconiosis Research Unit; particularly Dr. J. C. Gilson, Director, for valuable advice and criticism; Mr. J. Thomas, for statistical assistance and the members of the field survey team who helped with the collection and analysis of the material.

\section{REFERENCES}

Becklake, M. R., Zwi, S., and Lutz, W. (1959). Brit. J. industr. Med.,

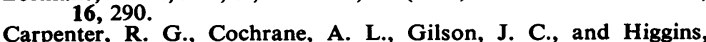
I. T. T. (1956). Ibid., 13, 166 .

Carstens, M. Brinkmann, O., Lange, H. J., Meisterernst, A., and Schlicht, H. (1958), Arch. Gewerbepath. Gewerbehyg., 16, 203. Cochrane, A. L. (1958). Marc Daniels Memorial lecture. (Royai College of Physicians, London.)

and Higgins, I. T. T. (1961). In the press.

-, Cox, J G, and Jarman, T. F. (1952). Brit. med. J., $2,843$. Davies, I., Chapman, P. J., and Rae, S. (1956). Brit. J. industr. Med., 13, 231.

Cross, K. W., McDowell, L. A., and Posner, E. (1958). Brit. med. J., 1,862 .

Doll, R., and Bradford Hill, A. (1950). Ibid., 2, 739.

Higgins, I. T. T. (1957). Ibid., 2, 1198

(1960). In Industrial Pulmonary Diseases, eds. E. J. King and C. M. Fletcher. J. and A. Churchill, London. and Cochran, J. B. (1958). Tubercle (Lond.), 39, 296

Cochrane, A. L., Gilson, J. C., and Wood, C. H. (1959) Brit. J. industr. Med., 16, 255

Oldham, P. D., Cochrane, A. L., and Gilson, J. C. (1956) Brit. med. J., 2, 904.

International Labour Organization (1953). Third International Conference of Experts on Pneumoconiosis, Sydney, 1950

International Labour Office, Geneva.
Kemsley, W. F. F. (1950). Ann. Eugen. (Lond.), 15, 161.

McKerrow, C. B., McDermott, M., and Gilson, J. C. (1960). Lancet, $1,149$.

Olsen, H. C., and Gilson, J. C. (1960). Brit. med. J., 1, 450.

Pestiaux, J., Gielen, E., Degueldre, G., and Lavenne, F. (1955). Instit. hyg. des mines. Communication no. 130.

Registrar-General (1938). DecennialSupplement, England and Wales, 1931. Part IIa. Óccupational Mortality. H.M.S.O., London. 1931. Part IIa. Occupational Mortality. H.M.S.O., London. (1958). Decennial Supplement, England and Wales,
Occupational Mortality, Part II. H.M.S.O., London.

Worth, G. Gasthaus, L., Lühning, W., Muysers, K., Siehoff, F., and Werner, K. (1959). Arch. Gewerbepath. Gewerbehyg., $17,396$. Valentin, H., Gasthaus, L., Hoffman, H., and Venrath, H. (1955). Ibid., 14, 37. 